\title{
ATMOSPHERIC N DEPOSITION IN CENTRAL AND SOUTHERN CHILE. AN OVERVIEW
}

\author{
DEPOSITACION ATMOSFERICA DE NITROGENO EN EL CENTRO Y SUR DE \\ CHILE. UN RESUMEN
}

\author{
Roberto Godoy ${ }^{1}$, Leandro Paulino ${ }^{1}$, Carlos Oyarzún ${ }^{2} \&$ Pascal Boeckx $^{3}$
}

\begin{abstract}
Temperate forests in Chile are not yet affected by elevated nitrogen (N) deposition. However, anthropogenic activities such as transport, industry and agriculture have been increasing in central and southern Chile. These activities can substantially alter the atmospheric $\mathrm{N}$ load and subsequently $\mathrm{N}$ deposition. Nitrogen deposition data for central and southern Chile are scares and scattered. In order to assess trends of $\mathrm{N}$ deposition a good knowledge of past and current $\mathrm{N}$ depositions is however essential. This study presents an overview of the existing $\mathrm{N}$ deposition data in Chile.

In central Chile, dry deposition has been estimated at $0.8 \mathrm{~kg} \mathrm{NO}_{3}^{-}-\mathrm{N} \mathrm{ha}^{-1} \mathrm{yr}^{-1}$ and $1.0 \mathrm{~kg} \mathrm{NH}_{4}{ }^{+} \mathrm{N}$ $\mathrm{ha}^{-1} \mathrm{yr}^{-1}$, giving a total of $1.8 \mathrm{~kg} \mathrm{~N} \mathrm{ha}^{-1} \mathrm{yr}^{-1}$ and wet deposition was $0.4 \mathrm{~kg} \mathrm{NO}_{3}-\mathrm{N} \mathrm{ha}^{-1}$ and $0.6 \mathrm{~kg} \mathrm{NH}_{4}{ }^{+} \mathrm{N}$ $\mathrm{ha}^{-1} \mathrm{yr}^{-1}$, giving a total of $1.0 \mathrm{~kg} \mathrm{~N} \mathrm{ha}^{-1} \mathrm{yr}^{-1}$. In southern Chile, inorganic $\mathrm{N}$ deposition via rainwater are less than $1.0 \mathrm{~kg} \mathrm{~N} \mathrm{ha}^{-1} \mathrm{yr}^{-1}$ in the coast range and $<5.0 \mathrm{~kg} \mathrm{~N}$ $\mathrm{ha}^{-1} \mathrm{yr}^{-1}$ in the Andes. The $\mathrm{N}$ input via cloudwater in the coast range was estimated at $1.1 \mathrm{~kg} \mathrm{NO}_{3}^{-}-\mathrm{N} \mathrm{ha}^{-1} \mathrm{yr}^{-}$ ${ }^{1}$ and $0.9 \mathrm{~kg} \mathrm{NH}_{4}^{+}-\mathrm{N} \mathrm{ha}^{-1} \mathrm{yr}^{-1}$, versus $1.0 \mathrm{~kg} \mathrm{NO}_{3}^{-}-\mathrm{N}^{3} \mathrm{ha}^{-}$ ${ }^{1} \mathrm{yr}^{-1}$ and $1.4 \mathrm{~kg} \mathrm{NH}_{4}{ }^{+}-\mathrm{N} \mathrm{ha}^{-1} \mathrm{yr}^{-1}$ the Andean mountains. Organic $\mathrm{N}$ input in rainwater can be a substantial $\mathrm{N}$ input in temperate forests of southern Chile. Deposition of organic $\mathrm{N}$ in Andes has been reported at $8.2 \mathrm{~kg} \mathrm{~N} h a^{-1} \mathrm{yr}^{-1}$. This values is 11-fold higher than in the coast range $\left(0.7 \mathrm{~kg} \mathrm{~N} \mathrm{ha}^{-1} \mathrm{yr}^{-1}\right)$.
\end{abstract}

Keywords: Atmospheric deposition, central and southern Chile, mineral N, organic N.

${ }^{1}$ Instituto de Botánica, Universidad Austral de Chile, Casilla 567, Valdivia, Chile. Corresponding author: Roberto Godoy. E-mail: rgodoy@uach.cl

${ }^{2}$ Instituto de Geociencias, Universidad Austral de Chile, Casilla 567, Valdivia, Chile.

${ }^{3}$ Laboratory of Applied Physical Chemistry - ISOFYS, Ghent University, Coupure 653, B-9000, Belgium.

\section{RESUMEN}

Los bosques templados de Chile aun no han sido afectados por una elevada depositación de nitrógeno $(\mathrm{N})$. Sin embargo, las actividades antropogénicas como el transporte, industria y agricultura se han incrementado en la región centro y sur de Chile. Estas actividades pueden sustancialmente alterar la carga atmosférica de nitrógeno y su consecuente depositación. Información sobre depositación atmosférica de $\mathrm{N}$ para el centro y sur de Chile esta escasa y dispersa. El poseer un registro de la depositación de nitrógeno, es esencial para un buen conocimiento de la situación pasada y actual. Este estudio presenta una revisión de la información de $\mathrm{N}$ depositación en Chile. En Chile central, la depositación seca fue estimada en $0,8 \mathrm{~kg} \mathrm{NO}_{3}^{-}-\mathrm{N} \mathrm{ha}^{-1}$ año ${ }^{-1}$ y $1,0 \mathrm{~kg} \mathrm{NH}_{4}^{+}-\mathrm{N} \mathrm{ha}^{-1}$ año ${ }^{-1}$, con un total de $1,8 \mathrm{~kg} \mathrm{~N} \mathrm{ha}^{-1} \mathrm{año}^{-1}$. La depositación húmeda fue de $0,4 \mathrm{~kg} \mathrm{NO}_{3}^{-}-\mathrm{N} \mathrm{ha}^{-1} \mathrm{año}^{-1}$ y $0,6 \mathrm{~kg}$ $\mathrm{NH}_{4}^{+}-\mathrm{N} \mathrm{ha}^{-1}$ año $^{-1}$ con un total de $1,0 \mathrm{~kg} \mathrm{~N}^{-1}$ año ${ }^{-1}$. En el Sur de Chile, la depositación de $\mathrm{N}$-inorgánico vía precipitación en la Cordillera de la Costa fue $<1,0 \mathrm{~kg}$ $\mathrm{N} \mathrm{ha}^{-1}$ año $^{-1}$ y en la Cordillera de los Andes inferior a $5,0 \mathrm{~kg} \mathrm{~N}^{-1} \mathrm{año}^{-1}$. Por otro lado, el ingreso de nitrógeno estimado vía neblina en la Cordillera de la Costa fue de $1,1 \mathrm{~kg} \mathrm{NO}_{3}^{-}-\mathrm{N} \mathrm{ha}^{-1} \mathrm{año}^{-1}$ y $0,9 \mathrm{~kg} \mathrm{NH}_{4}^{+}-\mathrm{N} \mathrm{ha}^{-1}$ año ${ }^{1}$, mientras en la Cordillera de los Andes con 1,0 y 1,4 $\mathrm{kg} \mathrm{N} \mathrm{ha}^{-1}$ año ${ }^{-1}$ para el nitrato y amonio, respectivamente. La entrada de $\mathrm{N}$ orgánico a través del agua de lluvia podría tener una contribución sustancial en los bosques templados del sur de Chile. Estimaciones de la depositación de $\mathrm{N}$ orgánico en la Cordillera de los Andes presenta valores 11 veces mayor $(8,2 \mathrm{~kg} \mathrm{~N}$ ha${ }^{1}$ año $\left.^{-1}\right)$ que en los bosques de la Cordillera de la Costa $\left(0,7 \mathrm{~kg} \mathrm{~N} \mathrm{ha}^{-1} \mathrm{año}^{-1}\right)$.

Palabras claves: Depositación atmosférica, $\mathrm{N}$ mineral, $\mathrm{N}$ orgánico. 


\section{INTRODUCTION}

Continental Chile has a length of more than 4,300 $\mathrm{km}$, a narrow width $(160 \mathrm{~km})$ and varying relief. The vegetation of the Mediterranean-type climate between $30^{\circ} \mathrm{S}$ to $37^{\circ} \mathrm{S}$ in central Chile is dominated by schrubland and dry sclerophyllous forest (Gajardo 1994). In the mild temperate climate further south $\left(37^{\circ}\right.$ to $\left.40^{\circ} \mathrm{S}\right)$, deciduous forests once predominated, although they have largely disappeared due to human settlement (Neira et al. 2002). Broadleaf evergreen forests are found mainly in humid climates south of latitude $40^{\circ}$ (Gajardo 1994).

The precipitation chemistry in southern Chile is one of the cleanest in the world (Weathers \& Likens 1997). Temperate forests in Chile are not yet affected by elevated $\mathrm{N}$ deposition, as is the case for forests in Europe or northeastern North America (Perakis \& Hedin 2002). However, anthropogenic activities such as transport, industry and agriculture have been increasing in central and southern Chile. These activities can substantially alter the atmospheric $\mathrm{N}$ load and enhance $\mathrm{N}$ input on forest ecosystems in Chile.

In general, $\mathrm{N}$ is a limiting nutrient in natural terrestrial ecosystems, especially in temperate forests (Rennenberg \& Gessler 1999; Schulze 2000). However, enhanced N input via atmospheric deposition has accelerated the terrestrial $\mathrm{N}$ cycle in some areas of the world (Vitousek \& Field 2001). Microbial processes in forest soils, metabolic processes in trees, and the functioning of forest ecosystem are considered to be better adapted to $\mathrm{N}$ limitation than to N excess (Schulze 2000; Vitousek $\&$ Field 2001). Increased N deposition may result in enhanced acidification and eutrophication of the soil, ground and surface water.

In order to better understand the processes governing $\mathrm{N}$ deposition, total deposition is separated into wet, cloud and dry deposition, as well as mineral and organic N (Hedin 2000). Wet deposition of chemical elements is associated with wet precipitation. Cloud deposition consists of elements dissolved in cloud or fog droplets that impact on to the vegetation. Dry deposition is the direct deposition of particles, aerosols and/or gases from the atmosphere on to the vegetation, soil or water (Steubing et al. 2001).

In 1983, Wiersma and collaborators were the first researchers in Chile to develop a network of long-term monitoring stations in remote areas, designed to evaluate many environmental key components (Wiersma et al. 1988, 1995). Weathers and Likens made similar efforts in 1987 in Torres del Paine National Park in southern Chile (Weathers \& Likens 1997). In recent years, many researchers have studied different aspects of biogeochemical cycles, nutrient fluxes and precipitation chemistry along continental Chile, especially in remote areas of southern Chile (Galloway et al. 1996; Hedin \& Hetherington 1996; Godoy et al. 2001; C. Oyarzún, R. Godoy, A. De Schrijver \& N. Lust, unpublished data); Perakis \& Hedin 2002; Salmon et al. 2001; Staelens et al. 2003; Uyttendaele \& Iroume 2002; Vann et al. 2002.).

Data of $\mathrm{N}$ deposition on temperate forest in Chile are scarse and scattered. In order to assess trends of $\mathrm{N}$ deposition a good knowledge of past and current $\mathrm{N}$ depositions is however, essential. This study presents an overview of the atmospheric deposition of $\mathrm{N}$ compounds $\left(\mathrm{NO}_{3}{ }^{-}, \mathrm{NH}_{4}{ }^{+}\right.$and organic-N) in central and southern Chile.

TABLE I. Wet and dry deposition of DIN (dissolved inorganic nitrogen) at Valparaíso (33 $\mathrm{S}, 15 \mathrm{~m}$ a.s.1.). Adapted from Prado-Fiedler \& Fuenzalida (1996).

\begin{tabular}{lccc}
\hline Deposition & $\begin{array}{l}\text { Nitrate-N } \\
\mathrm{kg} \mathrm{ha}^{-1} \mathrm{yr}^{-1}\end{array}$ & $\begin{array}{l}\text { Ammonium-N } \\
\mathrm{kg} \mathrm{ha}^{-1} \mathrm{yr}^{-1}\end{array}$ & $\begin{array}{c}\mathrm{DIN} \\
\mathrm{kg} \mathrm{ha}^{-1} \mathrm{yr}^{-1}\end{array}$ \\
\hline Wet & 0.4 & 0.6 & 1 \\
Dry & 0.8 & 1 & 1.8 \\
Total & 1.2 & 1.6 & 2.8 \\
\hline
\end{tabular}

\section{Central Chile}

Wet and dry $\mathrm{N}$ deposition in Valparaíso site near of the Pacific Ocean in central Chile $\left(33^{\circ} \mathrm{S}, 15 \mathrm{~m}\right.$ above sea level) has been investigated by PradoFiedler \& Fuenzalida (1996). This region has a mediterrannean type of climatic. It has an annual mean temperature of $14.8^{\circ} \mathrm{C}$ with a long dry season and rain concentrated in wintertime (mean annual precipitation of $380 \mathrm{~mm}$ ) (Di Castri \& Hajek 1976). For the monitored year the chemical concentration of the rainwater showed an extreme variability for nitrate- $\mathrm{N}$ (mean $=97 \mu \mathrm{g} \mathrm{L}^{-1}$, range $\left.=0-424 \mu \mathrm{g} \mathrm{L}^{-1}\right)$, and for ammonium-N (mean $=132 \mu \mathrm{g} \mathrm{L}{ }^{-1}$, range $=$ 0 -481 $\mathrm{g} \mathrm{L}^{-1}$ ) (Prado-Fiedler \& Fuenzalida 1996). Dry deposition has been estimated at $0.8 \mathrm{~kg}$ 
$\mathrm{NO}_{3}^{-}-\mathrm{N} \mathrm{ha}^{-1} \mathrm{yr}^{-1}$ and $1.0 \mathrm{~kg} \mathrm{NH}_{4}^{+}-\mathrm{N} \mathrm{ha}^{-1} \mathrm{yr}^{-1}$, giving a total of $1.8 \mathrm{~kg} \mathrm{~N} \mathrm{ha}^{-1} \mathrm{yr}^{-1}$ (Table I). Prado-Fiedler \& Fuenzalida (1996) confirmed that inorganic $\mathrm{N}$ compounds $\left(\mathrm{NO}_{3}^{-}+\mathrm{NH}_{4}^{+}\right)$in dry deposition showed a seasonal pattern with low values in summer and increasing values in wintertime. Wet deposition was $0.4 \mathrm{~kg} \mathrm{NO}_{3}^{-}-\mathrm{N} \mathrm{ha}^{-1}$ and $0.6 \mathrm{~kg} \mathrm{NH}_{4}^{+}-\mathrm{N} \mathrm{ha}^{-1} \mathrm{yr}^{-1}$, giving a total of $1.0 \mathrm{~kg} \mathrm{~N} \mathrm{ha}^{-1} \mathrm{yr}^{-1}$ (Table I). Thus, the sum of wet and dry deposition is $2.8 \mathrm{~kg} \mathrm{~N} \mathrm{ha}^{-1} \mathrm{yr}^{-1}$. The climatological patterns determine an overall dominance of dry over wet deposition. The reduced form of $\mathrm{N}$ was generally more abundant. The main factor, however, that regulates the variability of the wet deposition both for nitrate and ammonium, is the amount of rainfall (Prado-Fiedler \& Fuenzalida, 1996).

TABLE II. Mineral nitrogen concentrations in rainwater in southern Chile (adapted from Oyarzún et al. 2002).

\begin{tabular}{|c|c|c|c|c|c|c|}
\hline Site & $\begin{array}{l}\text { Altitude } \operatorname{Pre} \\
(\mathrm{m} \text { a.s.l. })\end{array}$ & $\begin{array}{l}\text { recipitation } \\
\left(\mathrm{mm} \mathrm{yr}^{-1}\right)\end{array}$ & $\mathrm{pH}$ & $\begin{array}{l}\text { Nitrate-N } \\
\left(\mathrm{mg} \mathrm{L}^{-1}\right)\end{array}$ & $\underset{\left(\mathrm{mg} \mathrm{L}^{-1}\right)}{\text { Ammonium-N }}$ & Forest type \\
\hline \multicolumn{7}{|l|}{ Coast range sites } \\
\hline $\begin{array}{l}\text { Alerce Costero Natural Monument } \\
\left(40^{\circ} 05^{\prime} \mathrm{S}\right)\end{array}$ & 820 & 4,098 & 5.4 & 43.2 & - & Fitzroya cupressoides \\
\hline $\begin{array}{l}\text { Chiloé National Park } \\
\left(42^{\circ} 30^{\prime} \mathrm{S}\right)\end{array}$ & $600-800$ & $0 \sim 3,000$ & - & $<30.0$ & $<50.0$ & Fitzroya cupressoides \\
\hline \multicolumn{7}{|l|}{ Andean sites } \\
\hline Puyehue National Park (40 47' S) & 1,120 & 6,560 & 6.1 & 9.8 & 39.5 & Nothofagus pumilio \\
\hline Puyehue National Park (40 47' S) & 1,120 & 5,330 & 5.7 & 26.2 & 45.4 & Nothofagus pumilio \\
\hline $\begin{array}{l}\text { Torres del Paine National Park } \\
\left(51^{\circ} 10^{\prime} \mathrm{S}\right)\end{array}$ & $50-400$ & $\sim 500$ & - & 7 & 8.4 & Nothofagus pumilio \\
\hline
\end{tabular}

TABLE III. Mineral and organic N concentrations (mean and range) of cloud water in Chiloé National Park (adapted from Weathers et al. 2000) and Puyehue National Park (adapted from Oyarzún et al.2003).

\begin{tabular}{lccc}
\hline Site & $\begin{array}{c}\mathrm{NO}_{3}^{-}-\mathrm{N} \\
\left(\mathrm{mg} \mathrm{L}^{-1}\right)\end{array}$ & $\begin{array}{c}\mathrm{NH}_{4}^{+}-\mathrm{N} \\
\left(\mathrm{mg} \mathrm{L}^{-1}\right)\end{array}$ & $\begin{array}{c}\text { Organic N } \\
\left(\mathrm{mg} \mathrm{L}^{-1}\right)\end{array}$ \\
\hline Chiloé National Park $(\mathrm{n}=17)$ & $69(9-224)$ & $71(7-168)$ & $602(34-4,118)$ \\
Puyehue National Park $(\mathrm{n}=12)$ & $87(33-141)$ & $109(6-251)$ & - \\
\hline
\end{tabular}

\section{Southern ChILE}

Several biogeochemical studies have been carried out most in humid temperate forest ecosystems between $40^{\circ}$ and $43^{\circ} \mathrm{S}$. The annual mean temperature is 5 to $12^{\circ} \mathrm{C}$ and precipitation ranges from 2,000 to 7,000 mm (Godoy et al. 1999; Oyarzún \& Godoy 2002; C. Oyarzún, R. Godoy, A. De Schrijver \& N. Lust, unpublished data).
Another important study site is the remote Torres del Paine National Park $\left(51^{\circ} \mathrm{S}\right)$. The climate at this site is classified as cold steppe and the annual precipitation is about $500 \mathrm{~mm} \mathrm{yr}^{-1}$ (Weathers \& Likens 1997).

Mean annual $\mathrm{N}$ composition of the rainwater in the coastal Cordillera and Andean 
Cordillera $\left(41^{\circ}-43^{\circ} \mathrm{S}\right)$ varied between $<30.0$ $43.2 \mathrm{NO}_{3}^{-}-\mathrm{N} \mu \mathrm{g} \mathrm{L}{ }^{-1}$ and $9.8-26.2 \mathrm{NO}_{3}^{-}-\mathrm{N} \mu \mathrm{g} \mathrm{L}^{-1}$, respectively (Table II). Similarly, the $\mathrm{NH}_{4}{ }^{+} \mathrm{N}$ concentrations were $<50 \mu \mathrm{g} \mathrm{NH}_{4}^{+}-\mathrm{NL}^{-1}$ and between 39.5 and $45.4 \mu \mathrm{g} \mathrm{NH}_{4}{ }^{+}-\mathrm{NL}^{-1}$ for the Coastal Cordillera and Andean Cordillera, respectively (Table II). Forests in the coast Cordillera are located immediately near the ocean and are unique in this sense that external input of major elements are almost exclusively due to sea aerosols (Oyarzún et al. 1998; Hedin et al. 1995; Hedin \& Hatherington 1996). The rainwater chemistry from remote area of southern Chile $\left(51^{\circ} \mathrm{S}\right)$ in a Nothofagus pumilio (Poepp. et Endl.) Krasser. forest showed mean values of $7.0 \mu \mathrm{g} \mathrm{NO}_{3}^{-} \mathrm{N} \mathrm{L}^{-1}$ and $8.4 \mu \mathrm{g} \mathrm{NH}_{4}^{+}-\mathrm{N} \mathrm{L}^{-1}$. This results is negligible quantities of mineral $\mathrm{N}$ deposition, specially under very low rainfall (Weathers \& Likens (1997) (Table II).

Since trees act as efficient filters, forest can capture a large amount of atmospheric deposition, especially occult deposition. Normally, mountain forest ecosystems are very efficient in trapping nutrients, specially nitrogen and cations from clouds and fogs (Weathers 1999). It has been suggested that nitrogen via cloud water is an important source for nutrient input to Chilean forest ecosystems of (Weathers \& Likens 1997; Weathers 1999; Weathers et al. 2000). In Chiloé National Park $\left(42^{\circ} \mathrm{S}\right)$ the nitrogen concentrations of cloud water showed an average concentration of $68.6 \mu \mathrm{g} \mathrm{NO}_{3}^{-}-\mathrm{N} \mathrm{L}^{-1}, 71.4$ $\mu \mathrm{g} \mathrm{NH}_{4}{ }^{+}-\mathrm{N} \mathrm{L}^{-1}$ and $602.3 \mu \mathrm{g} \mathrm{N} \mathrm{L}^{-1}$ as organic-N (Weathers et al. 2000) (Table III). For the Andean Cordillera in the Antillanca site of Puyehue National Park $\left(40^{\circ} \mathrm{S}\right)$, an analysis of 12 cloud/fog samples showed an average concentration of $87.1 \mathrm{NO}_{3}{ }^{-} \mathrm{N}$ $\mu \mathrm{g} \mathrm{L}^{-1}$ and 108.6 $\mathrm{NH}_{4}^{+}{ }^{-} \mathrm{N} \mu \mathrm{g} \mathrm{L}^{-1}$ (C. Oyarzún, R. Godoy, A. De Schrijver \& N. Lust, unpublished data: see Table III). The mineral $\mathrm{N}$ content for both coast and Andean Cordillera sites is very similar, but special attention should be given to the high contribution of organic $\mathrm{N}$ input in Chiloé as an important source to nitrogen limited forest ecosystems in the temperate region of southern Chile (Weathers \& Likens 1997). However, data from arid lands of northern Chile (El Tofo, coast Cordillera $\left(29^{\circ} \mathrm{S}, 780 \mathrm{~m}\right.$ a.s.1,), showed very high $\mathrm{N}$ concentrations in cloudwater, ranging from 75 to $2,150 \mu \mathrm{g} \mathrm{L}-1$ and 310 to $2,480 \mu \mathrm{g} \mathrm{L}^{-1}$ for $\mathrm{NO}_{3}^{-}{ }^{-} \mathrm{N}$ and $\mathrm{NH}_{4}{ }^{+}-\mathrm{N}$, respectively (Schemenauer \& Cereceda 1992).

TABle IV. Nitrogen deposition ( $\mathrm{kg} \mathrm{N} \mathrm{ha}^{-1} \mathrm{yr}^{-1}$ ) via cloud and rain water in Chiloé National Park (adapted from Weathers et al. 2000), and Puyehue National Park (adapted from C. Oyarzún, R. Godoy, A. De Schrijver \& N. Lust, unpublished data). $\mathrm{DIN}=$ dissolved inorganic nitrogen, $\mathrm{DON}=$ dissolved organic nitrogen.

\begin{tabular}{|c|c|c|c|c|c|}
\hline \multirow[t]{2}{*}{ Site } & \multicolumn{2}{|c|}{$\begin{array}{c}\text { DIN } \\
(\text { Cloudwater }) \\
\end{array}$} & \multirow[t]{2}{*}{$\begin{array}{c}\text { D ON } \\
(\mathrm{Cloudwater})\end{array}$} & \multicolumn{2}{|c|}{$\begin{array}{c}\text { DIN } \\
(\mathrm{R} \text { ainwater })\end{array}$} \\
\hline & $\mathrm{NO}_{3}{ }^{-}-\mathrm{N}$ & $\mathrm{NH}_{4}^{+}-\mathrm{N}$ & & $\mathrm{NO}_{3}^{-}-\mathrm{N}$ & $\mathrm{NH}_{4}{ }^{+}-\mathrm{N}$ \\
\hline Chiloé National Park & 1.1 & 0.9 & 9 & \multicolumn{2}{|c|}{$<1.0$} \\
\hline Puyehue National Park & 1.0 & 1.4 & $?$ & 0.6 & 3.0 \\
\hline
\end{tabular}

Data from Chiloé National Park for nitrate$\mathrm{N}$, ammonium- $\mathrm{N}$ and organic- $\mathrm{N}$ deposition via cloud water were estimated as $1.1 \mathrm{~kg} \mathrm{~N} \mathrm{ha}^{-1} \mathrm{yr}^{-1}, 0.9$ $\mathrm{kg} \mathrm{N} \mathrm{ha}^{-1} \mathrm{yr}^{-1}$ and $9.0 \mathrm{~kg} \mathrm{~N}^{-1} \mathrm{yr}^{-1}$, respectively (Table IV). Inorganic $\mathrm{N}$ deposition in Puyehue National Park via cloud water was estimated as 1.0 and $1.4 \mathrm{~kg} \mathrm{~N} \mathrm{ha}^{-1} \mathrm{yr}^{-1}$ for nitrate and ammonium, respectively (Table IV). These figures are high, relative to the range reported by Weathers et al. (2000) for coastal forest ecosystems at similar latitudes $\left(0.3-2.0 \mathrm{~kg} \mathrm{~N} \mathrm{ha}^{-1} \mathrm{yr}^{-1}\right)$. There are no data on organic $\mathrm{N}$ deposition via cloud water for Puyehue National Park.

The organic $\mathrm{N}$ input via rainwater can be substantial in temperate forests of southern Chile. Deposition of organic-N in a Nothofagus betuloides (Mirb.) Oerst forest in Puyehue National Park was $8.2 \mathrm{~kg} \mathrm{~N} \mathrm{ha}^{-1} \mathrm{yr}^{-1}$. This value is 11 fold higher than in the coastal Cordillera in Fitzroya cupressoides (Mol). Johnston forest $\left(0.7 \mathrm{~kg} \mathrm{~N} \mathrm{ha}^{-1} \mathrm{yr}^{-1}\right)$ (Oyarzún et al. 1998; C. Oyarzún, R. Godoy, A. De Schrijver $\&$ N. Lust, unpublished data). 
Recently, it has been shown that $\mathrm{N}$ loss from unpolluted forests located in southern Chile occurs mainly via dissolved organic nitrogen (DON) (Perakis \& Hedin, 2002.). The DON/DIN ratio in the hydrological loss from unpolluted Chilean forest increases with increasing rainfall (Perakis \& Hedin 2001, 2002). It is not yet clear whether DON originates directly from precipitation input or is produced biotically or abiotically in the soil. Oyarzún et al. (2002) indicated also that rainfall was the main factor controling the DON/DIN loss ratio in a Nothofagus forest for sites in Puyehue National Park with annual precipitation of 7,000 $\mathrm{mm}$.

Nitrogen deposition from other areas in southern Chile can be summarized as follows. Wet deposition of inorganic $\mathrm{N}$ was less than $1.0 \mathrm{~kg} \mathrm{~N}$ $\mathrm{ha}^{-1} \mathrm{yr}^{-1}$ in a region with conifer forest (Fitzroya cupressoides) in the Coastal Cordillera ( $820 \mathrm{~m}$ a.s.1.) and less than $5.0 \mathrm{~kg} \mathrm{~N} \mathrm{ha}^{-1} \mathrm{yr}^{-1}$ in Nothofagus pumilio forests at a site at $1,120 \mathrm{~m}$ a.s.l. in the Andean Cordillera (Hedin et al. 1995; Oyarzún et al. 1998; C. Oyarzún, R. Godoy, A. De Schrijver $\&$ N. Lust, unpublished data). Mineral nitrogen deposition has been monitored for a period of nine months at a site in the Coastal Cordillera, near the city of Valdivia $\left(40^{\circ} \mathrm{S}, 114 \mathrm{~m}\right.$ a. s. 1.), with a mixture of natives forests and plantations of Pinus radiata D. Don (Uyttendaele \& Iroume 2002). The mean nitrate concentration in rain water was 380 $\mu \mathrm{g} \mathrm{L}^{-1}$ and the total $\mathrm{NO}_{3}^{-}-\mathrm{N}$ was $6.3 \mathrm{~kg} \mathrm{~N} \mathrm{ha}^{-1}$, an unexpectedly high level compared to others studies in Chile. The ammonium concentration was generally below the detection limit. However, the estimated $\mathrm{NH}_{4}-\mathrm{N}$ deposition ranged between $0.3-$ $0.8 \mathrm{~kg} \mathrm{~N} \mathrm{ha}^{-1}$. Uyttendaele \& Iroume (2002) indicating that local biomass burning (house heating and forestry practices) may have influenced precipitation chemistry in this region.

Oyarzún et al. (2002) evaluated the atmospheric deposition of $\mathrm{N}$ compounds $\left(\mathrm{NO}_{3}{ }^{-}\right.$and $\left.\mathrm{NH}_{4}{ }^{+}\right)$ via wet deposition along an altitudinal transect from an agricultural livestock farming area located in the central valley, near Osorno city $\left(40^{\circ} 35^{\prime} \mathrm{S}, 55 \mathrm{~m}\right.$ a.s.1.) to a Nothofagus forests in the Andean Cordillera site, Antillanca, Puyehue National Park (4046' $\mathrm{S}, 1,120$ ma.s.1.). Ammonium-N concentrations in the precipitation in the agricultural region (annual mean $\left.=699.4 \mu \mathrm{g} \mathrm{L}^{-1}\right)$ were high compared to those of $\mathrm{NO}_{3}^{-}-\mathrm{N}$ (annual mean $=52.3 \mu \mathrm{g} \mathrm{L}^{-1}$ ). Inorganic-
$\mathrm{N}$ values show a marked seasonal variation in the agricultural region showing maximum values in spring-summer and minimum values in wintertime. The annual mean $\mathrm{NH}_{4}{ }^{+}-\mathrm{N}$ and $\mathrm{NO}_{3}{ }^{-}-\mathrm{N}$ concentration in precipitation in the Nothofagus forest of Andean Cordillera were lower than on farmland, decreasing to 37.8 and $6.9 \mu \mathrm{g} \mathrm{N} \mathrm{L}^{-1}$, respectively. The annual atmospheric deposition of $\mathrm{NO}_{3}^{-}-\mathrm{N}$ fluctuated between 0.5 and $0.6 \mathrm{~kg} \mathrm{~N} \mathrm{ha}^{-1} \mathrm{yr}^{-1}$ and the $\mathrm{NH}_{4}{ }^{+}-\mathrm{N}$ deposition varied between 6.4 and 2.8 $\mathrm{kg} \mathrm{N} \mathrm{ha}^{-1} \mathrm{yr}^{-1}$ in the agricultural region of Osorno and forest region of Antillanca in the Andean Cordillera, respectively.

Another important aspect is the contribution of dry deposition as potential input of nutrients to the forest ecosystems. Preliminary estimates of dry deposition during 3 months (November 2000 until January 2001) showed average values of $2.5 \mathrm{~kg} \mathrm{~N}$ ha $^{-1}$ month $^{-1}$ during summer in the central valley near Osorno (Oyarzún et al. 2002).

Cattle pastures located in the central valley are responsible for about $70 \%$ to the national milk production and $45 \%$ of national meat production in Chile (Salazar et al. 2003). As a consequence, substantial amounts of $\mathrm{NH}_{3}$ can be emitted from pastures, cowsheds, dung and manure or mineral fertilizer applications, which in turn can be captured by the forests of the Andean Cordillera. The total ammonia emission from this agriculture region was estimated at 5,623 ton $\mathrm{NH}_{3}{ }^{+}-\mathrm{N} \mathrm{yr}^{-1}$ (Salazar et al. 2003). In general, the low values for $\mathrm{NO}_{3}{ }^{-}$along the transect indicate a minor influence of fossil fuelrelated activities in this region (Oyarzún etal.2002).

\section{CONCLUSIONS}

For the coastal site of central Chile, a value of 2.8 $\mathrm{kg} \mathrm{N} \mathrm{ha}{ }^{-1} \mathrm{yr}^{-1}$ is indicated for wet plus dry mineral $\mathrm{N}$ deposition. Climatological patterns determine an overall dominance of dry over wet deposition. This estimate is very low and similar to values found in remote areas near the Pacific ocean in southern Chile.

In southern Chile, the deposition of inorganic $\mathrm{N}$ via precipitation is less than $1.0 \mathrm{~kg} \mathrm{~N} \mathrm{ha}^{-1} \mathrm{yr}^{-1}$ in the coastal Cordillera and less than $5.0 \mathrm{~kg} \mathrm{~N} \mathrm{ha}^{-1}$ $\mathrm{yr}^{-1}$ for the Andean Cordillera. However, these values could be underestimated, since input of cloudwater is often not assessed. Data from Chiloé 
for nitrate- $\mathrm{N}$ and ammonium- $\mathrm{N}$ deposition via cloud water were estimated as $0.7 \mathrm{~kg} \mathrm{~N} \mathrm{ha}^{-1} \mathrm{yr}^{-1}$ and $1.3 \mathrm{~kg}$ $\mathrm{N}$ ha $^{-1} \mathrm{yr}^{-1}$, respectively. Inorganic $\mathrm{N}$ deposition of cloud water in Andean Cordillera site (Antillanca) was estimated as 1.0 and $1.4 \mathrm{~kg} \mathrm{~N} \mathrm{ha}^{-1} \mathrm{yr}^{-1}$ for nitrate and ammonium respectively. Deposition of organic$\mathrm{N}$ in the forest in the Andean Cordillera, Puyehue National Park was $8.2 \mathrm{~kg} \mathrm{~N} \mathrm{ha}^{-1} \mathrm{yr}^{-1}$, a figure 11fold higher than that estimated for the coastal Cordillera (0.7 $\left.\mathrm{kg} \mathrm{N} \mathrm{ha}^{-1} \mathrm{yr}^{-1}\right)$.

The main source of ammonia is cattle production, which is concentrated in the central valley of the Chilean Lakes District $\left(40-42^{\circ} \mathrm{S}\right)$, and total emission was estimated at 5,623 ton $\mathrm{NH}_{3}-\mathrm{N}$. The contribution of dry $\mathrm{N}$ deposition is a potential source of nutrients to forest ecosystems as well. Preliminary estimates for dry deposition showed average values of $2.5 \mathrm{~kg} \mathrm{~N} \mathrm{ha}^{-1}$ month $^{-1}$ for the summer period in the central valley.

\section{ACKNOWLEDGMENTS}

The authors wish to thank the Fondecyt Project $\mathrm{N}^{\mathrm{o}}$ 1020989, Mecesup AUS 0103, Millenium Nucleus FORECOS P01-057-F and the Bilateral Scientific and Technological Cooperation between Flanders and Chile (Project BIL 99/4). L. Paulino thanks CONICYT for funding his PhD scholarship. We also thank editor C. Lusk for providing many comments and helpful review of the manuscript.

\section{REFERENCES}

Di Castri, F. \& E.R. Hajek. 1976. Bioclimatología de Chile. Vicerrectoría Académica, Universidad Católica de Chile. Santiago, Chile. 128 pp.

Gajardo, R. 1994. La vegetación natural de Chile. Clasificación y distribución geográfica. Editorial Universitaria. Santiago. 165 pp.

Galloway, J.N., W.C. KeEne \& G. LiKens. 1996. Processes controlling the composition of precipitation at a remote southern hemisphere location: Torres del Paine National Park, Chile. Journal of Geophysical Research 101: 6883-6987.

Godoy, R., C. Oyarzún, \& J. Bahamondes. 1999. Flujos hidroquímicos en un bosque de Nothofagus pumilio en el Parque Nacional Puyehue, sur de Chile. Revista Chilena de Historia Natural 72: 579-594.

Godoy, R., C. Oyarzún \& V. Gerding. 2001. Precipitation chemistry in deciduous and evergreen Nothofagus forest of southern Chile under a low- deposition climate. Basic and Applied Ecology 2: 65-72.

Hedin, L.O. 2000. Deposition of nutrients and pollutants to ecosystems. In: Methods in Ecosystems Science (eds O. Sala, H. Jakson, H. Mooney \& R. Howarth), pp. 265-276. Springer Verlag, Germany.

Hedin, L.O. \& E. D. Hetherington. 1996. Atmospheric and geologic constrains on the biogeochemistry of North and South American temperate rain forest. In: High Latitude Rainforest and associated Ecosystems of the West Coast of the Americas, Climate, Hydrology, Ecology, and Conservation. Ecological Studies 116 (eds R. Lawford, P. Alaback \& E. Fuentes), pp. 57-74. Springer Verlag, Germany.

Hedin, L.O., J.J. Armesto \& A.H. Johnson. 1995. Patterns of nutrient from unpolluted, old-growth temperate forest: evaluation of biogeochemical theory. Ecology 76: 493-509.

Neira, E., H. Verscheure \& C. Revenga. 2002. Chile's frontier forest: conserving a global treasure. Global Resources Institute, CODEF, Universidad Austral de Chile, Valdivia. 55 p.

Oyarzún, C., R. Godoy \& A. Sepúlveda. 1998. Water and nutrient fluxes in a cool temperate rainforest at the Cordillera de la Costa in southern Chile. Hydrological Processes 12: 1067-1077.

Oyarzún, C. \& R. Godoy. 2002. Canopy and soil interactions of atmospheric deposition in Nothofagus forest of southern Chile. In: Comparison of ecosystems functioning and biogeochemical cycles in temperate forest in southern Chile and Flanders (eds. A. De Schrijver, V. Kint, V.\& N. Lust), pp. 13-18. Academic Press,

Oyarzún, C., R. Godoy \& S. Leiva. 2002. Depositación atmosférica de nitrógeno en un transecto valle longitudinal-Cordillera de los Andes, centro-sur de Chile. Revista Chilena de Historia Natural 75: 233-243.

Prado-Fiedler, R. \& H. Fuenzalida. 1996. Wet and dry deposition of nitrogen compound in the southeast Pacific coast: Montemar, central Chile. Journal of Geophysical Research 101: 22845-22853.

Perakis, S. \& L.O. Hedin. 2001. Fluxes and fates of nitrogen in soil of an unpolluted old-growth temperate forest, southern Chile. Ecology 82(8): 2245-2260.

Perakis, S. \& L.O. Hedin. 2002. Nitrogen loss from unpolluted South American forest mainly via dissolved organic compounds. Nature 415: 416419.

Rennenberg, H. \& A. Gessler. 1999. Consequences of $\mathrm{N}$ deposition to forest ecosystems- recent results and future research needs. Water Air and Soil Pollution 116: 47-64.

Salazar, F., J. Dumont, M. Santana, B. Pain, D. Chadwick \& E. Owen. 2003. Prospección del manejo y utilización de afluentes de lecherías en el sur de Chile. Archivos de Medicina Veterinaria (in press). 
SAlmon, C., M. Walter, L.O. Hedin, \& M. Brown, 2001. Hydrological controls on chemical export from an undisturbed old-growth Chilean forest. Journal of Hydrology 253: 69-80.

Schemenahuer, R. \& P. Cereceda. 1992. The quality of fog water collected for domestic and agricultural use in Chile. American Meteorology Society 31: 275-290.

Schulze, E. 2000. Carbon and Nutrient Cycling in European Forest Ecosystems. Ecological Studies 142, Springer Verlag, Germany. 550 pp.

Staelens , J. A. Schrijver, C. Oyarzún \& N. Lust. 2003. Comparison of dry deposition and canopy exchange of base cations in temperate hardwood forest in Flanders and Chile. Gayana Botánica 60(1): 9-16.

Steubing L., R. Godoy \& M. Alberdi. 2001. Métodos en Ecología Vegetal. Editorial Universitaria, Santiago. 345 pp.

Uyttendaele, G. \& A. Iroume. 2002. The solute budget of a forest catchment and solute fluxes within a Pinus radiata and a secondary native forest site, southern Chile. Hydrological Processes 16: 2521-2536.

Vann, D., A. Joshi, C. Pérez, A. Johnson, J. Frizano, D. Zarin \& J. Armesto. 2002. Distribution and cycling of $\mathrm{C}, \mathrm{N}, \mathrm{Ca}, \mathrm{Mg}, \mathrm{K}$, and $\mathrm{P}$ in three pristine, oldgrowth forest in the Cordillera de Piuché, Chile. Biogeochemistry 60: 25-47.

Vitousek, P.M. \& C.B. Field. 2001. Input/Output Balances and Nitrogen Limitations in Terrestrial
Ecosystems. In: Global Biogeochemical Cycles in the Climate System (eds E. Schulze; M Heimann, S. Harrison, E. Holland, J. Lloyd, I.C. Prentice \& D. Schimel), pp. 217-226. Academic Press, San Diego.

WeAthers, K. 1999. The importance of cloud and fog in the maintenance of ecosystems. Trends in Ecology and Evolution 14: 214-215.

Weathers, K. \& G. Likens. 1997. Clouds in southern Chile: an important source of nitrogen to nitrogen limited ecosystems? Environmental Science \& Technology 31: 210-213.

Weathers, K., G. Lovett, G. Likens \& N. Caraco. 2000. Cloudwater input of nitrogen to forest ecosystems in southern Chile: forms, fluxes, and sources. Ecosystems 3: 590-595.

Wiersma, G., T.P.O. Rourke, D.A. Bruns, C. Boelcke, A. Johnson \& L. Mc. Anulty. 1988. Integrated Monitoring Project at Torres del Paine National Park, Chile. Methodology and Data Report. Informal Report $N^{\circ}$ EGG EES 7966. Idaho National Engineering Laboratory. P.O. Box 1625. Idaho Falls, ID USA 83415.

Wiersma, G., G.J. White, D.A. Bruns \& I. Serey. 1995. Atmospheric trace element sampling at Torres del Paine National Park, Chile. Toxicological and Environmental Chemistry 49: 253-264. 